\title{
ANALISIS BREAK EVEN POINT USAHA KERIPIK PEDAS "MUSTIKA" DI KECAMATAN LANGSA BARO KOTA LANGSA
}

\author{
Supristiwendi ${ }^{1}$, Muhammad Jamil ${ }^{2}$ dan Parianto $^{2}$ \\ ${ }^{I}$ Dosen Fakultas Pertanian Universitas Samudra \\ ${ }^{2}$ Dosen Fakultas Pertanian Universitas Samudra \\ ${ }^{2}$ Mahasiswa Program Studi Agribisnis Fakultas Pertanian Universitas Samudra
}

\begin{abstract}
Abstrak
Penelitian ini bertujaun untuk mengetahui mengetahui dan menganalisis Break Event Point (BEP) usaha keripik pedas "Mustika" di Kecamatan Langsa Baro Kota Langsa. Penelitian ini menggunakan metode studi kasus. Objek dalam penelitian ini hanya dibatasi pada usaha keripik pedas "Mustika" yang sudah berproduksi di wilayah Kecamatan Langsa Baro Kota Langsa. Ruang lingkup penelitian ini meliputi, penggunaan bahan baku, penggunaan tenaga kerja, biaya produksi, produksi dan pendapatan. Waktu penelitian dilaksanakan pada bulan Maret sampai dengan April 2017.

Rata-rata produksi usaha keripik pedas "Mustika" sebesar 65.200,00 kilogram dengan harga Rp. 40.000,00 perkilogram dan nilai produksi Rp. 2.608.000.000,00 per tahun, maka di pendapatan bersih yaitu sebesar Rp.1.121.341.000,00 per tahun. Berdasarkan pada hasil penghitungan investasi, dimana rata-rata $\mathrm{BEP}$ unit $=914,91 \mathrm{~kg}$, sedangkan rata-rata BEP rupiah = Rp.36.596.387,94, maka usaha keripik pedas "Mustika" di daerah penelitian layak untuk dikerjakan bila ditinjau dari segi aspek finansial.
\end{abstract}

Kata Kunci: Usaha, BEP, Keripik Pedas, Finansial

\section{PENDAHULUAN}

Industri kecil perlu mendapat perhatian dikarenakan industri kecil tidak hanya memberikan penghasilan bagi sebagian angkatan kerja namun juga merupakan ujung tombak dalam upaya pengentasan kemiskinan. Selain itu, industri kecil juga dapat memberikan tambahan penghasilan bagi keluarga, juga berfungsi sebagai strategi dalam mempertahankan hidup di tengah krisis ekonomi masyarakat.

Defenisi home industry (IRT) ialah kegiatan usaha yang mempunyai modal awal yang sangat kecil, atau nilai kekayaan (asset) yang kecil dan jumlah yang kurang dari 5 orang. Usaha kecil adalah kegiatan ekonomi rakyat yang berskala kecil dalam memenuhi kriteria kekayaan bersih atau hasil penjualan tahunan serta kepemilikannya. Usaha kecil yang dimaksud disini meliputi juga usaha kecil informal dan usaha kecil tradisional. Adapun usaha informal adalah berbagai usaha yang belum terdaftar, belum tercatat, dan belum berbadan hukum, antara lain petani penggarapan, pedagang asongan, pedangang keliling, pedangan kaki lima, dan pemulung. Sedangkan usaha tradisional adalah usaha yang menggunakan alat produksi sederhana yang telah digunakan secara turun temurun dan atau berkaitan dengan seni dan budaya. (Pandji, 2007: 50).

Industri rumahan bagi sebagian orang adalah sebuah pilihan karena lapangan pekerjaan yang menjadi sangat menyempit. Namun, bagi sebagian orang memang sudah berniat membangun sejak lama karena menganggap industri rumahan adalah sebuah pekerjaan yang menyenangkan, mudah, sekaligus menguntungkan dengan berbagai alasan. Salah satu bentuk industri rumhan yang banyak adalah industri keripik.

Menurut Sulistyowti (1999:1), "keripik adalah makanan ringan (snack foot) yang tergolong jenis makanan creckers". Keripik adalah sejenis makanan ringan berupa irisan tipis dari umbi-umbian, buah-buahan, atau sayuran yang digoreng di dalam minyak nabati. Untuk menghasilkan rasa yang gurih dan renyah biasanya dicampur dengan adonan tepung yang diberi rempah tertentu. Keripik memiliki banyak varian rasa dari manis hingga pedas. Salah satu jenis keripik yang paling banyak peminatnya adalah keripik singkong. Usaha 
kecil keripik singkong merupakan salah satu produk makanan ringan yang banyak digemari konsumen. Seiring dengan meningkatnya permintaan konsumen, kini keripik singkong mulai diinovasikan menjadi keripik pedas dengan berbagai tingkatan level. Meskipun trend ini belum lama dikenal masyarakat luas, namun perkembangannya sudah pesat sehingga banyak produsen kripik singkong mulai beralih jalur dengan menambahkan ekstra pedas pada kripik singkong olahannya. Salah satunya adalah keripik pedas "Mustika".

$$
\text { Usaha keripik pedas "Mustika" }
$$

terletak di Kecamatan Langsa Baro Kota

Tabel 1. Produksi, harga dan Jumlah Penjualan Keripik Pedas "Mustika di Kecamatan Langsa Baro Kota Langsa.
Langsa. Usaha keripik pedas ini telah lama berjalan dan sudah dikenal di seluruh pelosok kota langsa. Usaha keripik pedas "Mustika" telah berdiri sejak tahun 2006 dan masih berproduksi sampai sekarang. Perkembangan usaha keripik pedas "Mustika" sudah biasa dikatakan layak karena usaha memproduksi keripik pedas yang terlus berlanjut dan berkesenambungan. Untuk mengetahui keadaan usaha keripik pedas "Mustika" di Kecamatan Langsa Baro Kota Langsa dapat dilihat pada tabel 1 berikut.

\begin{tabular}{|c|c|c|c|}
\hline Tahun & $\begin{array}{c}\text { Produksi } \\
(\mathrm{Kg})\end{array}$ & $\begin{array}{c}\text { Harga Jual } \\
(\mathrm{Rp} / \mathrm{Kg})\end{array}$ & $\begin{array}{c}\text { Jumlah Penjualan } \\
(\mathrm{Kg} / \mathrm{Tahun})\end{array}$ \\
\hline 2014 & 64.500 & 38.500 & 64.460 \\
2015 & 60.000 & 39.500 & 59.990 \\
2016 & 63.000 & 40.000 & 62.440 \\
\hline Rata-Rata & 62.500 & 39.333 & 62.297 \\
\hline
\end{tabular}

Sumber : Data Sekunder, 2016 (diolah) Dari tabel 1 di atas dapat dilihat bahwa ratarata produksi kerik pedas "Mustika" selama tiga tahun terakhir sebesar 62.500 kilogram/ tahun dengan harga rata-rata $\mathrm{Rp}$. 39.333dan jumlah penjualan sebesar 62.460 kilogram/ tahun. Produksi terbesar terdapat pada tahun 2014 sebesar 64.500 kilogram dengan harga Rp. 38.500 dan jumlah penjualan sebesar 64.460 kilogram/ tahun, sedangkan produksi terkecil terdapat pada tahun 2015 sebesar 63.000 kilogram dengan harga jual sebesar Rp. 39.500 dan jumlah penjualan sebesar 62.440 kilogram/ tahun.

Keripik pedas mustika merupakan salah satu pelopor keripik pedas yang memiliki ciri khas tersendiri serta merupakan satu-satunya usaha keripik yang memproduksi keripik pedas di Kecamatan Langsa Baro Kota Langsa. Karena faktor inilah yang akhirnya membuat produk keripik pedas mustika menjadi unik dan mudah dikenal masyarakat luas. Suatu industri dikatakan berhasil jika industri tersebut memberikan input yang lebih besar dari pada keuntungan yang lebih besar dari pada biaya yang harus dikeluarkan, begitu juga dengan industri keripik pedas "Mustika". Untuk mengetahui hal tersebut perlu dilakukan analisis kelayakan pada industri yang dijalankan, karena dengan melakukan analisis kelayakan secara finansial maka dapat memberikan informasi sebagai bahan penunjang dalam menjalankan usaha dan dapat meningkatkan nilai tambah pada pengusaha dalam menjalankan usahanya.

Dalam studi kelayakan bisnis ada beberapa aspek yang harus diteliti dalam merencanakan, memulai atau menjalan sebuah usaha, diantaranya aspek hukum, teknik, ekonomis, pasar, manajemen, sosial dan finansial. Namun dalam penelitian ini hanya aspek finansial saja yang diteliti yaitu biaya dan manfaat bagi pelaku usaha pembuatan keripik pedas itu sendiri dalam menjalankan usahanya. Menurut Prasetya dan Lukiastuti (2009:119) analisis Break Event Point adalah suatu analisis yang bertujuan untuk menemukan satu titik, dalam unit atau rupiah, yang menunjukkan biaya sama dengan pendapatan. Titik tersebut dinamakan titik BEP. Dengan mengetahui titik BEP, analis dapat mengetahui pada volume penjualan, berapa perusahaan mencapai titik impasnya, yaitu tidak rugi, tetapi juga tidak untung sehingga apabila penjualan melebihi titik itu, maka perusahaan mulai mendapatkan untung. Sedangkan menurut Herjanto (2008:151) menyatakan, analisis pulang pokok (break-Event analysis) adalah suatu analisis yang bertujuan untuk 
menemukan satu titik dalam kurva biayapendapatan yang menunjukkan biaya sama dengan pendapatan. Titik tersebut disebut sebagai titk pulang pokok (break Event point, BEP).

Upaya pengembagan pengolahan keripik pedas harus sejalan dengan peningkatan kualitas dan sistem pemasarannya, hal ini disebab oleh industriindustri agribisnis yang sukses memiliki fokus yang kuat pada pelanggan dan kebulatan komitmen pada pemasaran. Pada umumnya setiap industri bertujuan untuk memperoleh keuntungan dari hasil produk yang dihasilkan, diman dengan keuntungan itu pula industri berupaya untuk mengembangkan dan mempertahankan kontinuitas usahanya. Usaha keripik pedas "Mustika" di Kecamatan Langsa Baro Kota Langsa pada dasarnya sudah berkembang dan dikenal di Kota langsa. Melihat perkembangan tersebut penulis tertarik mengalisis Break Event Ponit (BEP) pada usaha keripik pedas "Mustika"

\section{Identifikasi Masalah}

Apakah usaha keripik pedas "Mustika" mencapai titik break Event point dan layak dijalankan di Kecamatan Langsa Baro Kota Langsa.

\section{Tujuan Penelitian}

Untuk mengetahui dan menganalisis Break Event Point (BEP) usaha keripik pedas "Mustika" di Kecamatan Langsa Baro Kota Langsa.

\section{Hipotesis}

Usaha keripik pedas "Mustika" secara analisis Break Event Point layak dijalankan di Kecamatan Langsa Baro Kota Langsa.

\section{METODE PENELITIAN \\ Lokasi, Objek, Ruang Lingkup dan Waktu Penelitian}

Penelitian ini menggunakan metode survey. Menurut Sugiyono (2012:6), "metode survey digunakan untuk mendapatkan data dari suatu tempat tertentu yang alamiah (bukan buatan), tetapi peneliti melakukan perlakuan dalam pengumpulan data misalnya dengan mengedarkan kuisioner, wawancara terstruktur dan sebagiannya (perlakuan tidak seperti eksperimen)".
Objek dalam penelitian ini hanya dibatasi pada usaha keripik pedas "Mustika" yang sudah berproduksi di wilayah Kecamatan Langsa Baro Kota Langsa. Ruang lingkup penelitian ini meliputi, penggunaan bahan baku, penggunaan tenaga kerja, biaya produksi, produksi dan pendapatan. Waktu penelitian dilaksanakan pada bulan Maret sampai dengan April 2017.

\section{Variabel dan Data yang Diteliti}

Sesuai dengan latar belakang, kerangka pemikiran dan hipotesis yang telah diformulasikan maka dibutuhkan variabel sebagai berikut:

Penggunaan Bahan Baku (kg/tahun)

Biaya Produksi (Rp/tahun)

Produksi (Ton/tahun)

Nilai Produksi (Rp/tahun)

Pendapatan (Rp/tahun)

Metode Analisis dan Pengujian Hipotesis. Biaya produksi dianalisis dengan rumus : $\mathrm{TC}=\mathrm{FC}+\mathrm{VC} . .($ Rahim, $2007:$ 166)

Nilai produksi dianalisis dengan rumus : TR $=$ Y $\times$ Py ...(Rahim, $2007: 166)$

Nilai pendapatan dianalisis dengan rumus :

Pd = TR - TC .(Rahim, $2007:$ 166)

Dimana :

$\mathrm{Pd}=$ Pendapatan $(\mathrm{Rp} / \mathrm{tahun})$

$\mathrm{TR}=$ Total Penerimaan (Rp/tahun)

$\mathrm{TC}=$ Total Biaya Produksi (Rp/tahun)

$\mathrm{Y}=$ Produksi (kg/tahun)

Py = Harga Produksi $(\mathrm{Rp} / \mathrm{kg})$

$\mathrm{FC}=$ Biaya Tetap (Rp/tahun)

$\mathrm{VC}=$ Biaya Variabel (Rp/tahun)

Analisis Break Even Point (BEP)

$$
\text { Menurut Ibrahim (2003:22) }
$$

menyatakan "Break Event Point (BEP) adalah titik pulang pokok di mana total revenue sama dengan total cost." Ada dua jenis perhitungan BEP, yaitu BEP Volume $(\mathrm{BEP}(\mathrm{Q}))$ dan $\mathrm{BEP}$ harga $(\mathrm{BEP}(\mathrm{RP}))$.

\section{HASIL PENELITIAN \\ DAN PEMBAHASAN \\ Karakteristik Usaha \\ Keripik Pedas Mustika}

Karakteristik usaha akan mempengaruhi hasil olah yang diperoleh pengusaha dari usaha keripik pedas. Semakin besar usaha keripik pedas maka semakin tinggi produksi keripik 
pedas yang di hasilkan. Usaha keripik pedas "Mustika" telah berdiri sejak tahun 2006 hingga sekarang. Usaha keripik pedas "Mustika" beralamat di Desa Paya Bujok Tunong Kecamatan Langsa Baro Kota Langsa.

\section{Penggunaan Tenaga Kerja}

Tenaga kerja merupakan salah satu faktor produksi yang sangat penting dalam kegiatan produksi keripik pedas "Mustika"di Kecamatan Langsa Baro Kota Langsa. Penggunaan tenaga kerja yang efisien dan efektif dapat mempengaruhi terhadap pengeluaran biaya produksi dalam menjalankan usaha keripik pedas. Tenaga kerja yang di gunakan pada usaha keripik Tabel 4. Rata-Rata Penggunaan Tenaga Kerja Pada Berbagai Fase Kegiatan Usaha Keripik Pedas "Mustika" di Kecamatan Langsa Baro Kota Langsa, 2018.

\begin{tabular}{|l|l|c|}
\hline No & \multicolumn{1}{|c|}{ Fase kegiatan } & $\begin{array}{c}\text { Penggunaan Tenaga Kerja } \\
\text { (HKP/Tahun) }\end{array}$ \\
\hline 1. & Pengupasan & 280 \\
2. & Pencucian & 200 \\
3. & Perajangan & 250 \\
4. & Penggorengan & 300 \\
5. & Pemberian Bumbu & 80 \\
6. & Pengemasan & 360 \\
7. & Pengangkutan dan Pemasaran & 220 \\
\hline
\end{tabular}

Sumber : Data primer diolah (2018).

Dari tabel 4 di atas dapat dilihat bahwa penggunaan tenaga kerja usaha keripik pedas "Mustika" per tahun adalah 1.690 HKP/ Tahun. Penggunaan tenaga kerja yang terbesar terdapat pada fase kegiatan pengemasan yaitu 360 HKP/ Tahun hal ini terjadi karena karena pengemasan harus dilakukan dengan cepat untuk mempertahankan kualitas produk sehingga membutuhkan bayak tenaga kerja. Sedangkan penggunaan tenaga kerja yang terkecil terdapat pada fase pengangkutan dan pemasaran yaitu $220 \mathrm{HKP} / \mathrm{Tahun}$, hal ini terjadi karena produk keripik pedak sudah banyka yang dipesan sehingga proses penganggkutan tidak membutuhkan bayak tenaga kerja. Upah tenaga kerja pada usaha keripik pedas "Mustika" adalah Rp. $50.000,00,-$ per HKP.

\section{Biaya Produksi}

Pengertian biaya produksi dalam penelitian ini adalah semua biaya yang di perlukan baik biaya yang di bayar maupun tidak di bayar dalam suatu proses produksi. Biaya produksi dalam penelitian ini di pedas meliputi : fase kegiatan Pengupasan singkong, pencucian, perajangan, penggorengan, pemberian bumbu pengemasan, pengangkutan dan pemasaran. Dalam menghitung besarnya pencurahan tenga kerja yang di serap untuk setiap fase kegiatan, seluruhnya di konversikan kedalam hari kerja pria (HKP) dengan berdasarkan upah yang berlaku pada saat penelitian, dimana satu HKP di artikan seorang tenaga kerja yang bekerja 6 jam rata-rata atau dengan upah yang di bayarkan sebesar Rp. 50.000,per hari kerja. Untuk lebih jelasnya rata-rata penggunaan tenaga kerja pada fase kegiatan usaha keripik pedas "Mustika" dapat di lihat pada tabel 4 berikut ini. klasifikasikan menjadi 2 yaitu : (a) biaya tetap (fixed cost) dan (b) biaya tidak tetap (variabel cost)/ biaya operasional. Biaya tetap yang di maksud dalam penelitian ini adalah biaya yang besar kecilnya tidak di pengaruhi oleh tingkat produksi yang di peroleh. Sedangkan biaya tidak tetap adalah semua biaya yang di keluarkan untuk memperoleh faktor-faktor produksi tidak tetap dan akan mempengaruhi produksi yang akan di hasilkan. Menurut Soekartawi (2006:12) "biaya tetap (fixed cost) ialah biaya yang tidak ada kaitannya dengan jumlah barang yang di produksi. Sedangkan biaya tidak tetap adalah semua biaya yang di keluarkan sangat tergantung dari berubah tidaknya usaha yang di jalankan".

Biaya tetap (fixed cost) dalam penelitian ini adalah sewa tempat dan penyusutan peralatan. Sedangkan biaya tidak tetap adalah biaya pembelian bahan baku dan biaya tenaga kerja. Untuk lebih jelasnya mengenai rata-rata penggunaan biaya produksi pada usaha keripik pedas "Mustika" 
Tabel 5. Rata-Rata Penggunaan Biaya Produksi Pada Usaha Keripik pedas "Mustika" di Kecamatan Langsa Baro Kota Langsa, 2018.

\begin{tabular}{|c|l|r|}
\hline \multirow{2}{*}{ No. } & \multicolumn{1}{|c|}{ Jenis biaya } & $\begin{array}{c}\text { Jumlah biaya produksi } \\
\text { (Rp.) }\end{array}$ \\
\hline 1 & Biaya Tetap & \\
& Sewa Tempat & $12.000 .000,00$ \\
& Penyusutan & $3.959 .000,00$ \\
\hline & Total FC & $15.959 .000,00$ \\
\hline 2 & Biaya Variabel & \\
& Singkong & $594.000 .000,00$ \\
& Gas & $9.000 .000,00$ \\
& Kayu Bakar & $3.000 .000,00$ \\
& Minyak Goreng & $747.500 .000,00$ \\
& Cabai Merah & $30.000 .000,00$ \\
& Garam & $2.700 .000,00$ \\
& Tenaga Kerja & $84.500 .000,00$ \\
\hline & Total Variabel & $1.470 .700 .000,00$ \\
\hline & Total Biaya Produksi & $1.486 .659 .000,00$ \\
\hline
\end{tabular}

Sumber : Data primer diolah (2018).

Dari tabel 5 di atas dapat di lihat bahwa total biaya produksi usaha keripik pedas "Mustika" sebesar Rp. 1.486.659.000,00 per tahun. Penggunaan biaya produksi yang terbesar terdapat pada jenis biaya variabel yaitu untuk biaya pembelian minyak goreng yaitu sebesar Rp. 747.500.000,00 per tahun. Sedangkan penggunaan biaya produksi yang terkecil terdapat pada jenis biaya pembelian garam yaitu sebesar Rp.2.700.000,00 per tahun.

\section{Produksi dan Nilai Produksi}

Nilai produksi dalam penelitian ini di maksudkan sebagai pendapatan kotor yang berasal dari hasil produksi keripik pedas yang telah di kalikan dengan harga masing-masing. Rata-rata sumber penerimaan usaha keripik pedas "Mustika" di Kecamatan Langsa Baro Kota Langsa dapat di lihat pada tabel 6 berikut ini.

Tabel 6. Rata-rata Produksi dan Nilai Produksi per tahun usaha keripik pedas di Kecamatan Langsa Baro Kota Langsa, 2018.

\begin{tabular}{|l|l|r|}
\hline No & \multicolumn{1}{|c|}{ Uraian } & $\begin{array}{c}\text { Nilai } \\
(\mathrm{Rp})\end{array}$ \\
\hline 1 & Produksi & $65.200,00$ \\
2 & Harga & $40.000,00$ \\
3 & Nilai Produksi & $2.608 .000 .000,00$ \\
\hline
\end{tabular}

Sumber : Data primer diolah (2018).

Dari tabel 6 di atas dapat di lihat bahwa rata-rata produksi usaha keripik pedas "Mustika" sebesar 65.200,00,- kilogram dengan harga Rp. 40.000,00,- perkilogram dan nilai produksi Rp. 2.608.000.000,00,- per tahun.

\section{Pendapatan}

Pendapatan dalam penelitian ini dapat di bedakan menjadi dua jenis yaitu pendapatan kotor dan pendapatan bersih. Pendapatan kotor adalah total hasil produksi yang di peroleh berupa keripik pedas dikslikan dengan harga. Sedangkan pendapatan bersih adalah selisih antara pendapatan kotor (penerimaan) dengan total pengeluaran (biaya produksi dari proses produksi bersangkutan).

Untuk lebih jelasnya tentang pendapatan kotor dan pendapatan bersih rata-rata pada usaha keripik pedas "Mustika" di Kecamatan Langsa Baro Kota Langsa dapat dilihat pada tabel 7 berikut ini. 
Tabel 7. Pendapatan Usaha Keripik pedas "Mustika" di Kecamatan Langsa Baro Kota Langsa, 2018.

\begin{tabular}{|c|l|c|}
\hline No & \multicolumn{1}{|c|}{ Uraian } & Nilai \\
\hline 1 & Nilai Produksi & $2.608 .000 .000,00$ \\
2 & Biaya Produksi & $1.486 .659 .000,00$ \\
3 & Pendapatan & $1.121 .341 .000,00$ \\
\hline
\end{tabular}

Sumber : Data primer diolah (2018).

Dari tabel 7 di atas dapat di lihat bahwa ratarata biaya produksi Usaha keripik pedas "Mustika" yang dikeluarkan yaitu sebesar Rp. 1.486.659.000,00 per tahun, maka diperoleh nilai produksi yaitu sebesar $\mathrm{Rp}$. 2.608.000.000,00 per tahun dan pendapatan bersih yaitu sebesar Rp. 1.121.341.000,00 per tahun.

Tabel 8. Indikator Penilaian Kelayakan Usaha Keripik Pedas "Mustika" di Kecamatan Langsa Baro Kota Langsa, 2018.

\begin{tabular}{|c|l|r|r|rr|}
\hline No & \multicolumn{1}{|c|}{$\begin{array}{l}\text { Indikator } \\
\text { Penilaian }\end{array}$} & Nilai BEP & Nilai Lapangan & \multicolumn{2}{|c|}{ Kriteria } \\
\hline 1 & & & & \\
2 & BEP unit & $914,91 \mathrm{Kg}$ & $65.200,00 \mathrm{~kg}$ & $>$ BEP & layak \\
& BEP rupiah & Rp 36.596.387,94 & Rp. 2.608.000.000,00 & $>$ BEP & layak \\
\hline
\end{tabular}

Sumber : Data primer diolah (2018).

Berdasarkan tabel 8 diatas dapat dilihat bahwa berdasarkan pada hasil penghitungan investasi, dimana rata-rata BEP unit $=914,91$ $\mathrm{kg}$, dimana nilai lapangan > BEP berarti terima Ha tolak Ho. Sedangkan ratarata $\mathrm{BEP}$ rupiah $=\mathrm{Rp} .36 .596 .387,94$, dimana nilai lapangan > BEP artinya terima Ha tolak Ho, maka usaha keripik pedas "Mustika" di daerah penelitian layak untuk dikerjakan bila ditinjau dari segi aspek finansial.

\section{Pembahasan}

Berdasarkan pada hasil penghitungan investasi, dimana dimana rata-rata BEP unit $=914,91 \mathrm{~kg}$, rata-rata sedangkan rata-rata $\mathrm{BEP}$ rupiah = Rp. 36.596.387,94 maka maka usaha keripik pedas "Mustika" di daerah penelitian layak untuk dikerjakan bila ditinjau dari segi aspek finansial. Hal ini terjadi karena tingginya produksi keripik pedas "Mustika" di Kecamatan Langsa Baro Kota Langsa sehingga pendapatan yang diperoleh pengusaha keripik pedas "Mustika"menjadi

\section{Analisis Break Even Point Usaha Keripik Mustika Di Kecamatan Langsa Baro Kota Langsa}

Kelayakan usaha keripik pedas "Mustika" dalam penelitian ini dianalisis dengan menggunaka alat analisis Break Even Point (BEP). Untuk lebih jelasnya mengenai indikator penilaian kelayakan usaha keripik pedas "mustika" di Kecamatan Langsa Baro Kota Langsa dapat dilihat pada table 8 berikut ini.

besar dan dapat menutupi biaya produksi yang dikeluarkan dalam kegiatan usaha keripik pedas. Usaha keripik pedas " Mustika" merupakan salah satu kegiatan usaha yang di lakukan oleh masyarakat, namun jumlahnya masih terbatas. Hal ini di sebabkan oleh tingginya modal investasi yang harus dikeluarkaan oleh pengusaha untuk mampu mendirikan usaha ini.

Kita ketahui bahwa usaha keripik pedas sangat menjanjikan karena mengolah hasil bumi yang berupa ubi yang di hasilkan petani lokal menjadi keripik yang memiliki nilai ekonomis tinggi. Keberadaan industri pembuatan keripik pedas ini sangat menunjang petani dalam memasarkan hasil pertanian terutama komoditas ubi karena dapat menambah nilai tambah produk produk singkong yaitu keripik pedas. Oleh karennya sangat diharapkan kepedulian pemerintah dalam hal ini, agar usaha ini dapat berkembang dengan baik dan dapat melayani kepentingan masyarakat umum. 


\section{KESIMPULAN DAN SARAN \\ Kesimpulan}

1. Pemilik usaha keripik pedas "Mustika" di Kecamatan Langsa Baro Kota Langsa berumur 48 tahun, dengan pendidikan selama 12 tahun, ini berarti tinggkat pendidikan pengusaha hanya tamat Sekolah Menengah Pertama (SMA), sedangkan penggalaman di bidang usaha keripik pedas selama 10,00 tahun. Dengan jumlah tanggungan 2 orang

2. Penggunaan tenaga kerja usaha keripik pedas "Mustika" per tahun adalah 1.690 HKP.

3. Total biaya produksi usaha keripik pedas "Mustika" sebesar Rp. 1.486.659.000,00 per tahun.

4. Rata-rata produksi usaha keripik pedas "Mustika" sebesar 65.200,00 kilogram dengan harga Rp. 40.000,00 perkilogram dan nilai produksi Rp.2.608.000.000,00 per tahun, maka di pendapatan bersih yaitu sebesar Rp.1.121.341.000,00 per tahun.

5. Berdasarkan pada hasil penghitungan investasi, dimana ratarata $\mathrm{BEP}$ unit $=914,91 \mathrm{~kg}$, sedangkan rata-rata $\mathrm{BEP}$ rupiah = Rp. 36.596.387,94, maka usaha keripik pedas "Mustika" di daerah penelitian layak untuk dikerjakan bila ditinjau dari segi aspek finansial.

\section{Saran}

1. Keuntungan/ laba yang di peroleh oleh usaha keripik pedas "Mustika" di Kecamatan Langsa Baro Kota Langsa harus menjadi salah satu unsur motivasi bagi pengusaha keripik lain untuk memperoleh keuntungan yang lebih besar dari masa mendatang.

2. Diharapkan kepada pemerintah dalam hal ini instansi terkait untuk terus memberi perhatian kepada usaha keripik agar usahanya dapat ditingkatkan ke arah yang lebih baik dalam rangka untuk melayani kepentingan masyarakat dan produksi yang dihasilkan dapat terjual dengan mudah di pasaran.

\section{DAFTAR PUSTAKA}

Abdul Halim dan Bambang Supomo. (2005). Akuntansi Manajemen. Edisi Pertama. Yogyakarta: BPFE.

Anonimos, 2015. Kecamatan Langsa Baro Dalam Angka 2015, BPS Kota Langsa.

Anoraga Pandji, 2007. Pengantar bisnis. Pengelolaan Bisnis Dalam Era Globalisasi. Jakarta: Rieneka Cipta

Adisasmita, Rahardjo, 2006, Pembangunan Pedesaan dan Perkotaan, Graha Ilmu Yogyakarta.

Bernardin, H. John. 2003. Human Resources Management: An Experiential Approach, 3rd edition, McGraw-Hill/Irwin, New York.

Creswell, John W. 2010. Research Design Pendekatan Kualitatif, Kuantitatif, dan Mixed, Pustaka Pelajar, Yogyakarta.

Fatah N., 1994. Evaluasi proyek Aspek Finansial pada Proyek Mikro. Cv. Asona Jakarta.

Herjanto, Eddy. 2008. Manajemen Operasi. Edisi Ketiga. Jakarta: Grasindo

Husein Umar, 2004, Metode Penelitian Untuk Skripsi Dan Tesis Bisnis, Cet ke 6, Jakarta : PT RajaGrafindo Persada.

Irsan Azhari Saleh, 2001.Industri Kecil Sebuah Tinjauan dan Perbandingan, Jakarta LP3ES.

Ibrahim, H.M.Yacob. 2003. Studi Kelayakan Bisnis. Edisi Revisi. Jakarta. Rineka Cipta.

Idham, A., Lestari, T. dan Adriani, D. (2010). Analisis finansial sistem usaha tani terpadu (integrated farming system) berbasis ternak sapi di kabupaten oganilir. Jurnal Pembangunan Manusia 6. http://balitbangdasumsel.net/ data/download/20100414125413.pdf. [3 April 2011].

Jatmiko, RD, 2004, Manajemen Strategik, Edisi Pertama, UMM Press, Malang.

Kamisa. 1997. Kamus Lengkap Bahasa Indonesia. Surabaya: Kartika Keppres RI No. 127 Tahun 2001 tentang Bidang/ Jenis Usaha yang Disadangkan Untuk Usaha Kecil dan Bidang/ Jenis Usaha yang Terbuka Untuk Usaha Menengah atau Besar Dengan Syarat Kemitraan. 
Kristina, 1993. Teknologi Bahan Makanan,

Mediyatama Sarana Perkasa, Jakarta. 